\section{OP0204 IMPACT OF ANTI-DRUG ANTIBODY AND INJECTION SITE REACTION ON EFFICACY: 24-WEEK RESULTS FROM A PHASE III STUDY COMPARING SB4 (ETANERCEPT BIOSIMILAR) WITH REFERENCE ETANERCEPT IN PATIENTS WITH RHEUMATOID ARTHRITIS}

J. Vencovsky ${ }^{1}$, P. Emery ${ }^{2}$, E. Keystone ${ }^{3}$, J. Ghil ${ }^{4}$, S.Y. Cheong ${ }^{4}$, E.E. Hong ${ }^{4}$

${ }_{1}^{1}$ Institute of Rheumatology, Prague, Czech Republic; ${ }^{2}$ Leeds Institute of

Rheumatic and Musculoskeletal Medicine, Leeds, United Kingdom; ${ }^{3}$ Mount Sinai

Hospital, Toronto, Canada; ${ }^{4}$ Samsung Bioepis Co., Ltd., Incheon, Korea, Republic Of

Background: SB4 is approved by the European Commission as a biosimilar of the reference etanercept (ETN). The phase III clinical study results have been reported previously. ${ }^{1,2}$ Data to date shows no correlation between the development of anti-drug antibody (ADA) and clinical response or adverse events with etanercept treatment.

Objectives: To investigate the impact of the presence of ADA or injection site reaction (ISR) on efficacy in patients with rheumatoid arthritis (RA) treated with SB4 or ETN up to week 24

Methods: In this phase III randomised, double blind study, patients with moderate to severe RA received $50 \mathrm{mg} /$ week of either SB4 or ETN with background methotrexate (MTX) for 52 weeks. Efficacy, safety and immunogenicity were assessed.

Results: Up to week 24, the incidence of ADA (2 patients [0.4\%] in SB4 vs 39 patients [13.1\%] in ETN, $p<0.001$ ) and the incidence of ISR (9 patients [3.0\%] in SB4 vs 48 patients [16.2\%] in ETN, $p<0.001$ ) were significantly lower in SB4 compared to ETN. Due to the low incidence of ADA in the SB4 treatment group, the impact of ADA on efficacy could not be evaluated. Within the ETN treatment group at week 24, there was a trend towards increased efficacy (ACR20, ACR-N, change in DAS28, remission and low disease activity based on DAS28, SDAl, or CDAI) in patients without detectable ADA compared to patients with ADA (Table). In regards to ISR, efficacy tended to be higher in patients who did not experience ISR compared to those who did within each treatment group.

There was no correlation between the presence of ADA and incidence of ISR. In patients without detectable ADA and patients with ADA, respectively, $3.0 \%$ (9/297) vs. $0.0 \%$ (0/2) of patients from SB4 group and $16.3 \%$ (42/248) vs. $15.4 \%$ $(6 / 39)$ of patients from the ETN group experienced ISR.

Table. Efficacy at week 24 by presence of ADA and ISR

\begin{tabular}{|c|c|c|c|c|}
\hline & \multicolumn{2}{|c|}{ SB4 50 mg } & \multicolumn{2}{|c|}{ ETN $50 \mathrm{mg}$} \\
\hline & $(+) \operatorname{ADA}(\mathrm{n}=2)$ & $(-)$ ADA $(n=297)$ & (+) $\mathrm{ADA}(\mathrm{n}=39)$ & $(-)$ ADA $(n=257)$ \\
\hline ACR20 & $2 / 2(100.0 \%)$ & $218 / 285(76.5 \%)$ & $24 / 36(66.7 \%)$ & $189 / 236(80.1 \%)$ \\
\hline ACR 50 & $1 / 2(50.0 \%)$ & $127 / 285(44.6 \%)$ & $15 / 36(41.7 \%)$ & $101 / 236(42.8 \%)$ \\
\hline ACR70 & $0 / 2(0.0 \%)$ & $69 / 285(24.2 \%)$ & $9 / 36(25.0 \%)$ & $50 / 236(21.2 \%)$ \\
\hline ACR-N & $48.8 \pm 19.38$ & $45.0 \pm 29.14$ & $40.3 \pm 30.33$ & $44.3 \pm 27.70$ \\
\hline Change in DAS28 & $-2.98 \pm 1.063$ & $-2.57 \pm 1.375$ & $-2.09 \pm 1.407$ & $-2.57 \pm 1.295$ \\
\hline Change in SDAI & $-33.50 \pm 3.394$ & $-25.69 \pm 14.641$ & $-23.78 \pm 15.230$ & $-25.37 \pm 12.831$ \\
\hline \multirow{2}{*}{ Change in CDAI } & $-32.65 \pm 4.596$ & $-24.73 \pm 14.120$ & $-22.45 \pm 14.396$ & $-24.57 \pm 12.750$ \\
\hline & (+) ISR (n=9) & $(-) \operatorname{ISR}(\mathrm{n}=290)$ & (+) ISR ( $n=48)$ & $(-)$ ISR $(n=249)$ \\
\hline ACR20 & $5 / 7(71.4 \%)$ & $215 / 280(76.8 \%)$ & $3039(76.9 \%)$ & $183 / 233(78.5 \%)$ \\
\hline ACR50 & $1 / 7(14.3 \%)$ & $127 / 280(45.4 \%)$ & $14 / 39(35.9 \%)$ & $102 / 233(43.8 \%)$ \\
\hline ACR 70 & $1 / 7(14.3 \%)$ & $68 / 280(24.3 \%)$ & $7 / 39(17.9 \%)$ & $52233(22.3 \%)$ \\
\hline ACR-N & $32.6 \pm 28.18$ & $45.3 \pm 29.06$ & $41.8 \pm 28.80$ & $44.1 \pm 27.95$ \\
\hline Change in DAS28 & $-1.81 \pm 1.282$ & $-2.59 \pm 1.371$ & $-2.31 \pm 1.280$ & $-2.54 \pm 1.324$ \\
\hline Change in SDAI & $-20.55 \pm 11.986$ & $-25.86 \pm 14.654$ & $-21.56 \pm 12.233$ & $-25.77 \pm 13.216$ \\
\hline Change in CDAI & $-20.17 \pm 11.462$ & $-24.88 \pm 14.140$ & $-20.74 \pm 12.062$ & $-24.89 \pm 13.036$ \\
\hline \multicolumn{5}{|c|}{ Data are presentedin eithern n' $(\%)$ or mea } \\
\hline $\begin{array}{l}\text { ACR20:50/70: American } \\
\text { antibody; CDAI clinical } \\
\text { activity; SDAI: simplifie }\end{array}$ & ityindex & & & $\begin{array}{l}\text {; ADA: anti-drug } \\
\mathrm{n} ; \mathrm{LDA}: \text { low disease }\end{array}$ \\
\hline
\end{tabular}

Conclusions: Significantly fewer patients from SB4 developed ADA or experienced ISR compared to ETN, however the efficacy was still comparable between SB4 and ETN in patients without detectable ADA and in patients who did not experience ISR. Within the ETN group, there was a trend towards increased efficacy in patients without detectable ADA compared to patients with ADA. In both SB4 and ETN group, patients with ISR tended to have higher efficacy than patients without ISR. There was no correlation between the presence of ADA and ISR.

\section{References:}

[1] Emery P et al. Ann Rheum Dis. 2015 Jul 07

[2] Vencovsky J et al. Arthritis Rheumatol. 2015; 67 (suppl 10).

Disclosure of Interest: J. Vencovsky Consultant for: Samsung Bioepis Co., Ltd., Biogen, P. Emery Grant/research support from: Abbvie, BMS, Pifzer, USB, MSD, Novartis, Lilly, Consultant for: Samsung Bioepis Co., Ltd., E. Keystone Grant/research support from: Abbott, Amgen, AstraZeneca, BMS, Janssen, Lilly, Novartis, Pfizer, Consultant for: Abbott, AstraZeneca, Biotest, BMS, Genentech, Janssen, Lilly, Merck, Pfizer, Samsung Bioepis, Speakers bureau: Abbott, AstraZeneca, BMS Canada, Janssen, J. Ghil Employee of: Samsung Bioepis Co., Ltd., S. Y. Cheong Employee of: Samsung Bioepis Co., Ltd., E. Hong Employee of: Samsung Bioepis Co., Ltd.

DOI: 10.1136/annrheumdis-2017-eular.3043

\section{THURSDAY, 15 JUNE 2017 Which target/outcome is more relevant in the management of SLE?}

\section{OP0205 ASSOCIATION BETWEEN T FOLLICULAR HELPER CELL AND PLASMABLAST CORRELATES WITH DISEASE ACTIVITY IN PATIENTS WITH SYSTEMIC LUPUS ERYTHEMATOSUS}

S. Nakayamada, S. Kubo, M. Yoshikawa, Y. Miyazaki, S. Iwata, I. Miyagawa, K. Nakano, K. Saito, Y. Tanaka. The First Department of Internal Medicine, Universitiy of Occupational and Environmental Health, Japan, Kitakyushu, Japan

Background: Various immunological abnormalities contribute to the development and perpetuation of systemic lupus erythematosus (SLE). Since SLE is a molecularly heterogeneous disease, targeted therapy has not yet been fully established. It seems to be important to explore the characteristic and interaction among the immune cell phenotypes in this disease.

Objectives: The aim of this study was to assess the relationship between the peripheral immune cell phenotypes with clinical manifestations and responsiveness to immunosuppressive therapy in patients with SLE.

Methods: Peripheral blood mononuclear cells were obtained from 143 SLE patients and 26 healthy donors (HD). The blood samples were taken at baseline and week 24 after treatment. The subset of circulating $B, T$ and dendritic cells was defined based on comprehensive 8-color flow cytometric analysis for human immune system termed "the Human Immunology Project" proposed by the National Institutes of Health $(\mathrm{NIH})$ and the Federation of Clinical Immunology Societies (FOCIS). The correlation of immune cell phenotypes with clinical characteristics and responsiveness to immunosuppressive therapies, such as cyclophosphamide, mycophenolate mofetil, or calcineurin, in addition to highdose glucocorticoids, were evaluated. Patients who were required more than two different immunosuppressant therapies in addition to glucocorticoids were considered treatment resistant.

Results: The frequency of $\mathrm{CD}^{+} \mathrm{CD}^{+} \mathrm{CXCR} 5^{+} \mathrm{ICOS}{ }^{+} \mathrm{T}$ follicular helper (Tfh) cell, but not $\mathrm{CD}^{+} \mathrm{CD}^{+}{ }^{+} \mathrm{CXCR} 3^{+} \mathrm{CCR} 6^{-}$Th 1 cell and $\mathrm{CD} 3^{+} \mathrm{CD} 4^{+} \mathrm{CXCR} 3^{-} \mathrm{CCR} 6^{+}$Th17 cell, were higher in SLE than that in HD (mean 1.1 vs $0.8, p=0.01$ ). The frequency

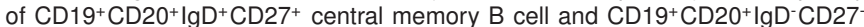
effector $B$ cell were higher in SLE than that in HD (mean 23.6 vs 15.1 and 10.7 vs $5.2, p \leq 0.001$ and $p<0.001$, respectively). The largest difference relative to the HD was observed in the proportion of $\mathrm{CD} 19^{+} \mathrm{CD} 20^{-} \mathrm{CD} 27^{+} \mathrm{CD} 38^{+}$plasmablast, which was higher in SLE (mean 16.2 vs $3.7, p<0001$ ) and correlated with BILAG index $(r=0.24, p<0.001)$. The proportion of Tfh cell significantly correlated with serum IgG level $(r=0.35, p<0.001)$, and the proportion of $\mathrm{CD}^{+} \mathrm{CD}^{+}{ }^{+} \mathrm{CXCR} 5^{+} \mathrm{ICOS}^{+}$ $\mathrm{CD}^{2} 9^{+}$activated $\mathrm{Tfh}$ cell correlated with serum anti-Sm antibody level $(r=0.26$, $\mathrm{p}=0.01$ ). Among helper $\mathrm{T}$ cell subsets (Th1, Th17, Treg and Tfh), the proportion of Tfh cell only showed positive correlation with that of plasmablast $(r=0.24$, $\mathrm{p}=0.02$ ). Treatment resulted in marked improvement in disease activity scores, such as SLEDAI and BILAG and resulted in significant decreased proportions of plasmablast and Tfh cell (plasmablast; mean 17.6 to 10.1, $p<0.01$, Tfh; mean 1.1 to $0.7, p<0.01)$. The percentage of patients who showed treatment resistance was highest among patients with high percentage of Tfh cell $(p=0.03)$.

Conclusions: Peripheral immuno-phenotyping confirmed the importance of Tfh cell and plasmablast in patients with SLE, i.e. activation of Tfh cell correlated with autoantibody production while plasmablast did with disease activity of SLE. Our findings supported the relevance of Tfh cell-plasmablast axis as a potential therapeutic target for SLE. The peripheral immunophenotyping might be useful in evaluating the pathogenesis and in determining the therapeutic target of each patient. Disclosure of Interest: S. Nakayamada: None declared, S. Kubo Speakers bureau: Bristol-Myers, M. Yoshikawa: None declared, Y. Miyazaki: None declared, S. Iwata: None declared, I. Miyagawa: None declared, K. Nakano: None declared, K. Saito: None declared, Y. Tanaka Grant/research support from: Mitsubishi-Tanabe, Takeda, Daiichi-Sankyo, Chugai, Bristol-Myers, MSD, Astellas, Abbvie, Eisai, Speakers bureau: Abbvie, Chugai, Daiichi-Sankyo, Bristol-Myers, Mitsubishi-Tanabe, Astellas, Takeda, Pfizer, Teijin, Asahi-kasei, YL Biologics, Sanofi, Janssen, Eli Lilly, GlaxoSmithKline

DOI: 10.1136/annrheumdis-2017-eular.4165

\section{OP0206 PERFORMANCE OF SLEDAI-2K TO DETECT A CLINICALLY MEANINGFUL CHANGE IN SLE DISEASE ACTIVITY: A 36-MONTH PROSPECTIVE COHORT STUDY OF 334 PATIENTS}

D. Jesus ${ }^{1}$, M. Rodrigues ${ }^{1}$, A. Matos ${ }^{2,3}$, C. Henriques ${ }^{2,3,4}$, J. da Silva ${ }^{5,6}$ L. Inês ${ }^{1,6,7} .{ }^{1}$ CHUC Lupus Clinic, Rheumatology Department, Centro Hospitalar e Universitário de Coimbra, Coimbra; ${ }^{2}$ School of Technology and Management, Polytechnic Institute of Viseu; ${ }^{3}$ Centre for the Study of Education, Technologies and Health, Viseu; ${ }^{4}$ Centre for Mathematics; ${ }^{5}$ CHUC Lupus Clinic, Rheumatology Department; ${ }^{6}$ Faculty of Medicine, University of Coimbra, Coimbra; ${ }^{7}$ Faculty of Health Sciences, University of Beira Interior, Covilhã, Portugal

Background: The Systemic Lupus Erythematosus Disease Activity Index (SLEDAI) is the core determinant of response in the SLE Responder Index (SRI), a primary efficacy outcome in SLE clinical trials. However, SLEDAI is unable to discriminate partial improvement/worsening, as it scores each item 